Article

\title{
The Potential Biotechnological Applications of the Exopolysaccharide Produced by the Halophilic Bacterium Halomonas almeriensis
}

\author{
Inmaculada Llamas, Hakima Amjres, Juan Antonio Mata, Emilia Quesada and Victoria Béjar * \\ Microbial Exopolysaccharide Research Group, Department of Microbiology, Faculty of Pharmacy, \\ Campus Universitario de Cartuja, University of Granada, 18071 Granada, Spain; \\ E-Mails: illamas@ugr.es (I.L.); amjresha@yahoo.fr (H.A.); jonanmg@hotmail.com (J.A.M.); \\ equesada@ugr.es (E.Q.)
}

* Author to whom correspondence should be addressed; E-Mail: vbejar@ugr.es; Tel.: +34-958-241-705; Fax: +34-958-216-035.

Received: 31 March 2012; in revised form: 31 May 2012 / Accepted: 5 June 2012 /

Published: 12 June 2012

\begin{abstract}
We have studied the extracellular polysaccharide (EPS) produced by the type strain, $\mathrm{M} 8^{\mathrm{T}}$, of the halophilic bacterium Halomonas almeriensis, to ascertain whether it might have any biotechnological applications. All the cultural parameters tested influenced both bacterial growth and polysaccharide production. EPS production was mainly growth-associated and under optimum environmental and nutritional conditions $\mathrm{M} 8^{\mathrm{T}}$ excreted about $1.7 \mathrm{~g}$ of EPS per litre of culture medium (about $0.4 \mathrm{~g}$ of EPS per gram of dry cell weight). Analysis by anion-exchange chromatography and high-performance size-exclusion chromatography indicated that the exopolysaccharide was composed of two fractions, one of $6.3 \times 10^{6}$ and another of $1.5 \times 10^{4}$ Daltons. The monosaccharide composition of the high-molecular-weight fraction was mannose $(72 \% \mathrm{w} / \mathrm{w})$, glucose $(27.5 \% \mathrm{w} / \mathrm{w})$ and rhamnose $(0.5 \% \mathrm{w} / \mathrm{w})$. The low-molecular-weight fraction contained mannose $(70 \% \mathrm{w} / \mathrm{w})$ and glucose $(30 \% \mathrm{w} / \mathrm{w})$. The EPS has a substantial protein fraction $(1.1 \% \mathrm{w} / \mathrm{w})$ and was capable of emulsifying several hydrophobic substrates, a capacity presumably related to its protein content. The EPS produced solutions of low viscosity with pseudoplastic behaviour. It also had a high capacity for binding some cations. It contained considerable quantities of sulphates $(1.4 \% \mathrm{w} / \mathrm{w})$, an unusual feature in bacterial polysaccharides. All these characteristics render it potentially useful as a biological agent, bio-detoxifier and emulsifier.
\end{abstract}


Keywords: extremophiles; halophilic bacteria; Halomonas almeriensis; exopolysaccharide; sulphates; heavy-metal chelation; emulsifying activity

\section{Introduction}

Exopolysaccharides (EPSs) are polymers consisting mainly of carbohydrates excreted by some bacteria and fungi onto the outside of their cell walls. They occur in two basic forms: as a capsule, where the polymer is closely associated with the cell surface, and as slime loosely associated with the cell surface. Their composition and structure vary greatly: they can be either homo- or heteropolysaccharides and may also contain a number of different organic and inorganic substituents. Most homopolysaccharides are neutral glucans, whilst the majority of heteropolysaccharides are polyanionic due to the presence of uronic acids. Furthermore, charge can be conferred by the presence of sulphate and phosphate groups, pyruvate ketals or succinyl hemiesters [1-4]. EPS production involves a significant expenditure of carbon and energy by microorganisms, an expenditure which must afford them some benefits. EPSs act as an adhesin and favour interactions and cellular associations amongst microorganisms, creating micro-environments within which the transfer of genes and metabolites is very common. Another important role is the protective function they provide against adverse physical and chemical factors or against attack by viruses and protists. Moreover, the production of EPSs provides a way for microorganisms to ensure their survival in nutrient-starved environments [2,5]. They have aroused great interest among biotechnologists because of their wide range of potential applications in such fields as pharmacy, foodstuffs, cosmetics and the petroleum industry, in which emulsifying, viscosifying, suspending and chelating agents are required $[4,6]$. During the past 50 years a considerable number of bacterial EPSs have been described but, with the exception of xanthan produced by Xanthomonas campestris and gellan produced by Sphigomonas paucimobilis, few have achieved great commercial success due either to their being unable to offer better properties than those already on the market or to difficulties in finding new applications [7].

A new approach to encountering polymers with novel properties might entail investigating different environments such as hypersaline habitats. Because of the extreme nature of hypersaline environments they might be expected to harbour unusual microorganisms of biotechnological interest and so for the last few years we have been carrying out a wide research programme, screening microorganisms from such habitats in an attempt to find new EPSs with different characteristics. Noteworthy among the halophilic bacteria, the main EPS producers, are eleven species from Halomonadaceae [8-18], three species of the family Alteromonadaceae [19,20], the type species of the genera Salipiger and Palleronia [21,22] and the halophilic cyanobacterium Aphanotece halophytica [23]. Among these polymers the following are outstanding: mauran, produced by Halomonas maura, which, in a similar way to xanthan, produces highly viscous aqueous solutions [24-26]; the polymers produced by Halomonas eurihalina, which gel at acid $\mathrm{pH}$ and have high emulsifying capacity [27-31]; the EPSs produced by Halomonas ventosae, Halomonas anticariensis, Idiomarina fontislapidosi, Idiomarina ramblicola and Alteromonas hispanica, which have emulsifying properties [32,33]; and the EPS produced by Salipiger mucescens, which contains a substantial quantity of fucose, a monosaccharide 
of great industrial interest in the fields of cosmetics and foodstuffs [34]. All these EPSs produced by halophilic bacteria have in common a high sulphate content $[18,25,26,32,33]$, which is unusual in EPSs from prokaryotes, with the exception of those from the halophilic archaea Haloferax mediterranei and Haloarcula japonica [35-37].

We describe here the EPS produced by Halomonas almeriensis, a species of halophilic bacteria originally isolated in our laboratory [13]. We have studied the influence of cultural parameters on the polymer's production and characterized it both physically and chemically to identify the properties that might make it suitable for biotechnological applications.

\section{Results}

\subsection{EPS Production}

Figure 1 shows the fermentation profile of the halophilic, EPS-producing bacterium H. almeriensis strain $\mathrm{M} 8^{\mathrm{T}}$ grown in $\mathrm{MY}$ complex medium containing $7.5 \% \mathrm{w} / \mathrm{v}$ total salts and an initial glucose concentration of $1 \% \mathrm{w} / \mathrm{v}$. Incubation was for eight days at $32{ }^{\circ} \mathrm{C}$ with orbital shaking at $100 \mathrm{rpm}$. Under these conditions maximum growth $\left(\mathrm{OD}_{600}=2.5\right)$ was reached after $120 \mathrm{~h}$. Glucose metabolism also lead to an exopolysaccharide accumulation of $1.7 \mathrm{~g} \cdot \mathrm{L}^{-1}(0.4 \mathrm{~g}$ of EPS per gram of dry cell weight) after five days. The kinetics of EPS production showed that it was excreted mainly during the exponential growth phase but continued slightly in the stationary phase, during which it was almost wholly released into the culture medium (Figure 2). Its degradation took place during the late stationary phase.

Figure 1. Profile of growth and EPS production by $H$. almeriensis strain $M 8^{\mathrm{T}}$ in $\mathrm{MY}$ medium at $7.5 \% \mathrm{w} / \mathrm{v}$ total salts with reference to glucose consumption. $(\boldsymbol{\Delta})$, optical density at $600 \mathrm{~nm} ;(\bullet)$, g EPS per litre of culture medium; (x), \% residual glucose.

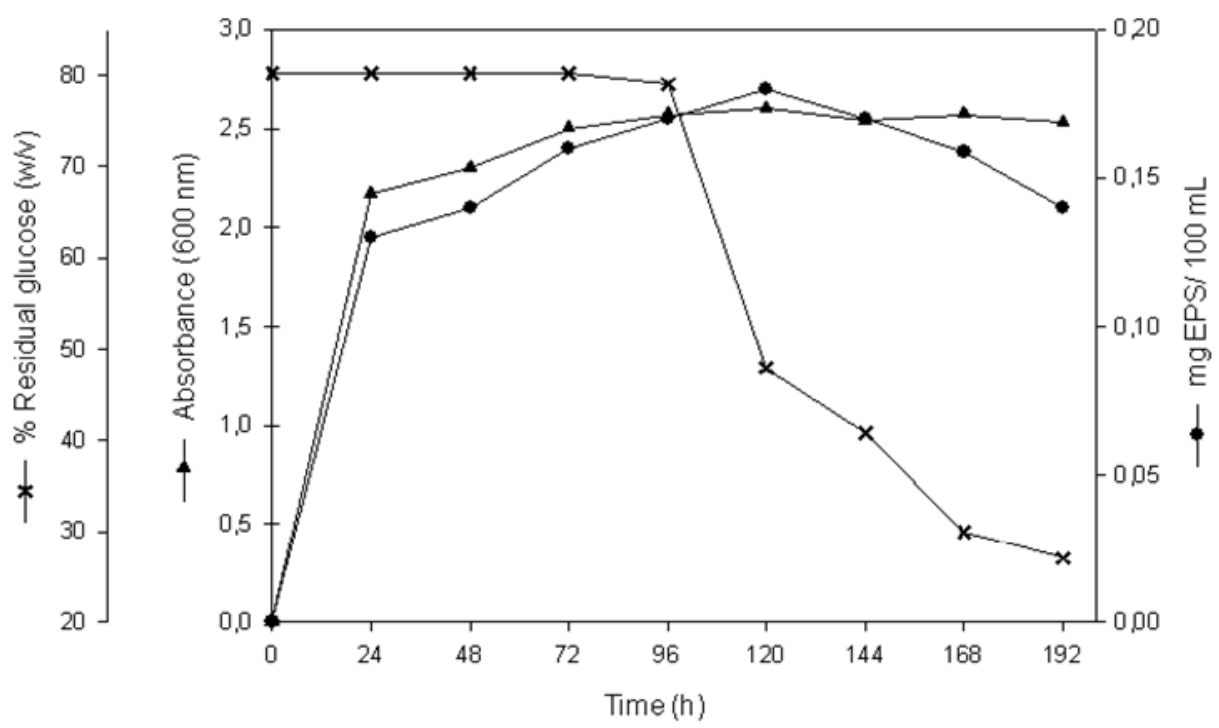


Figure 2. Electron micrographs showing EPS accumulation around $H$. almeriensis $\mathrm{M} 8^{\mathrm{T}}$ cells during exponential growth (A) and stationary phase $(\mathbf{B})$. Bars $=1 \mu \mathrm{m}$. Arrows indicate the EPS of the strain.

A

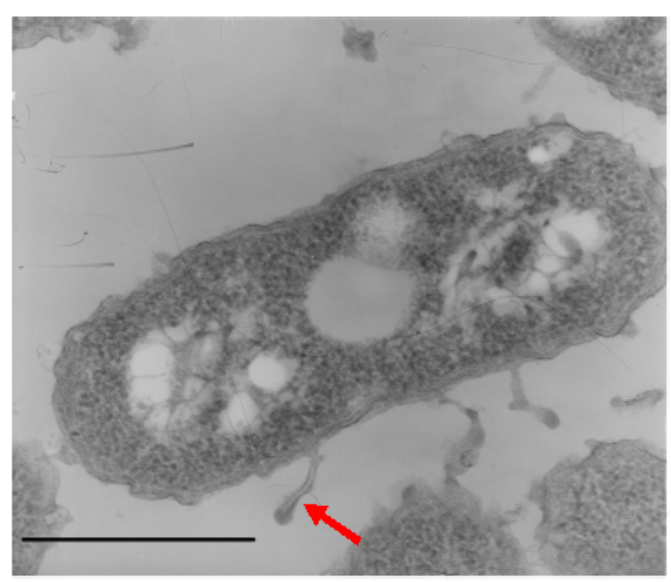

B

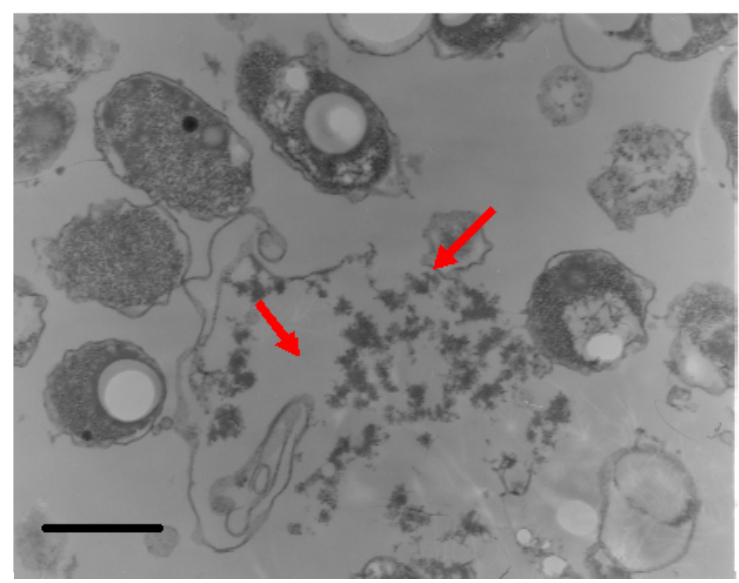

The effects of several cultural parameters, such as temperature $\left(22,32\right.$ and $\left.42{ }^{\circ} \mathrm{C}\right)$, shaking $(0,100$ and $200 \mathrm{rpm})$, total sea-salts $(2.5,5,7.5$ and $10 \% \mathrm{w} / \mathrm{v})$, glucose concentration $(0,1,2,5,7$ and 10\%) and sucrose, mannose and galactose as alternative carbon sources were analysed to find the ideal conditions for the synthesis of EPS by $H$. almeriensis $\mathrm{M}^{\mathrm{T}}$. Our results indicated that salt concentration had a significant effect on both biomass and EPS production, with a concentration of $7.5 \% \mathrm{w} / \mathrm{v}$ leading to the best bacterial growth and polysaccharide production. As far as glucose concentration was concerned, final biomass and EPS concentration were greater with $1 \% \mathrm{w} / \mathrm{v}$ glucose than with higher concentrations, until at 7\%-10\% w/v it inhibited both bacterial growth and EPS synthesis. When there is a lack of glucose, on the other hand, bacterial growth was not limited at all and EPS synthesis was detectable. Our strain could grow and produce its EPS with all the carbon sources assayed, although glucose was the most efficient. Three temperatures were tested: 22,32 and $42{ }^{\circ} \mathrm{C}$. Maximum EPS was obtained at $32{ }^{\circ} \mathrm{C}$. At both, $22{ }^{\circ} \mathrm{C}$ and $42{ }^{\circ} \mathrm{C}$ the yields were substantially lower, concomitant with a significant inhibition in bacterial growth. In the same way, both static incubation and an orbital shaking speed of $200 \mathrm{rpm}$ resulted in lower growth and lower polysaccharide yields (Table 1).

Tabla 1. Exopolysaccharide production of Halomonas almeriensis at different growth conditions.

\begin{tabular}{|c|c|c|c|c|c|c|c|c|c|c|c|c|}
\hline & \multicolumn{4}{|c|}{ Salt concentration ${ }^{a}(\%, w / v)$} & \multicolumn{8}{|c|}{ Incubation time $(\mathbf{h}){ }^{b}$} \\
\hline & 2.5 & 5 & $7.5 *$ & 10 & 24 & 48 & 72 & 96 & 120 * & 144 & 168 & 192 \\
\hline $\operatorname{EPS}(\mathrm{g} / 100 \mathrm{~mL})$ & 0 & 0.15 & 0.17 & 0.15 & 0.13 & 0.14 & 0.16 & 0.17 & 0.18 & 0.17 & 0.159 & 0.14 \\
\hline
\end{tabular}

\begin{tabular}{cccccccccccc}
\multicolumn{3}{c}{$\left.\begin{array}{c}\text { Incubation } \\
\text { temperature }\left({ }^{\circ} \mathbf{C}\right)\end{array}\right)$} & \multicolumn{4}{c}{ Shaking speed (rpm) } & \multicolumn{6}{c}{ Glucose concentration $(\mathbf{\%}, \mathbf{w} / \mathbf{v}){ }^{\mathbf{e}}$} \\
\hline $\mathbf{2 2}$ & $\mathbf{3 2} *$ & $\mathbf{4 2}$ & $\mathbf{0}$ & $\mathbf{1 0 0} *$ & $\mathbf{2 0 0}$ & $\mathbf{0}$ & $\mathbf{1} *$ & $\mathbf{2}$ & $\mathbf{5}$ & $\mathbf{7}$ & $\mathbf{1 0}$ \\
\hline 0.015 & 0.17 & 0.02 & 0.035 & 0.17 & 0.085 & 0.13 & 0.17 & 0.15 & 0.14 & 0 & 0 \\
\hline
\end{tabular}

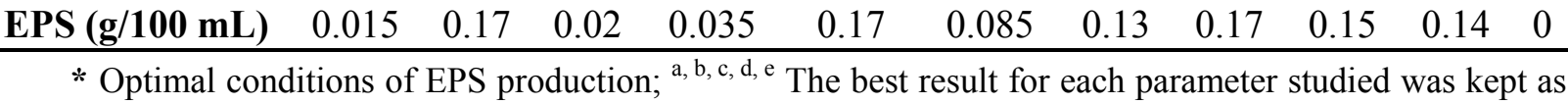
constant for the following studies. 


\subsection{Chemical Composition and Molecular Mass}

The EPS excreted by $H$. almeriensis $\mathrm{M} 8^{\mathrm{T}}$ was a heteropolysaccharide. The native polymer was composed mainly of carbohydrates $(30.5 \% \mathrm{w} / \mathrm{w})$ but it also contained other organic compounds such as acetyl residues $(0.8 \% \mathrm{w} / \mathrm{w})$, pyruvate $(2 \% \mathrm{w} / \mathrm{w})$, hexosamines $(2.4 \% \mathrm{w} / \mathrm{w})$ and proteins $(1.1 \% \mathrm{w} / \mathrm{w})$, and a significant inorganic fraction (near $60 \% \mathrm{w} / \mathrm{v}$ ) containing a considerable quantity of sulphates $(1.4 \% \mathrm{w} / \mathrm{w})$ and phosphates $(0.15 \% \mathrm{w} / \mathrm{w})$. It also proved to be an anionic polymer because of its numerous negative charges. It was strongly adsorbed onto an anion-exchange QMA Sep-Pak cartridge. It was eluted with $\mathrm{NaCl}$ concentrations from 0.5 to $2 \mathrm{M}$. No retention was observed when the polymer was loaded on a cation-exchange CM Sep-Pak cartridge. In an attempt to assess its charge distribution it was loaded on an anion-exchange column and eluted using a linear ionic strength gradient. The presence of two chromatographic peaks attested to the fact that the polysaccharide from $H$. almeriensis $\mathrm{M} 8^{\mathrm{T}}$ contained at least two species (Figure 3). As for its molecular mass, the HPSEC elution pattern and size-distribution analysis of the EPS showed two peaks of $6.3 \times 10^{6} \mathrm{Da}$ and $1.5 \times 10^{4} \mathrm{Da}$. The main components of the high-molecular-weight fraction of the EPS from $\mathrm{H}$. almeriensis were glucose $(27.5 \% \mathrm{w} / \mathrm{w})$ and mannose $(72 \% \mathrm{w} / \mathrm{w})$, and there were also small quantities of rhamnose $(0.5 \% \mathrm{w} / \mathrm{w})$. The low-molecular-weight fraction contained glucose $(30 \% \mathrm{w} / \mathrm{w})$ and mannose $(70 \% \mathrm{w} / \mathrm{w})$.

Figure 3. Anion-exchange chromatogram of the EPS synthesised by H. almeriensis $\mathrm{M} 8^{\mathrm{T}}$. (A: $6.3 \times 10^{6}$ Daltons, B: $1.5 \times 10^{4}$ Daltons).

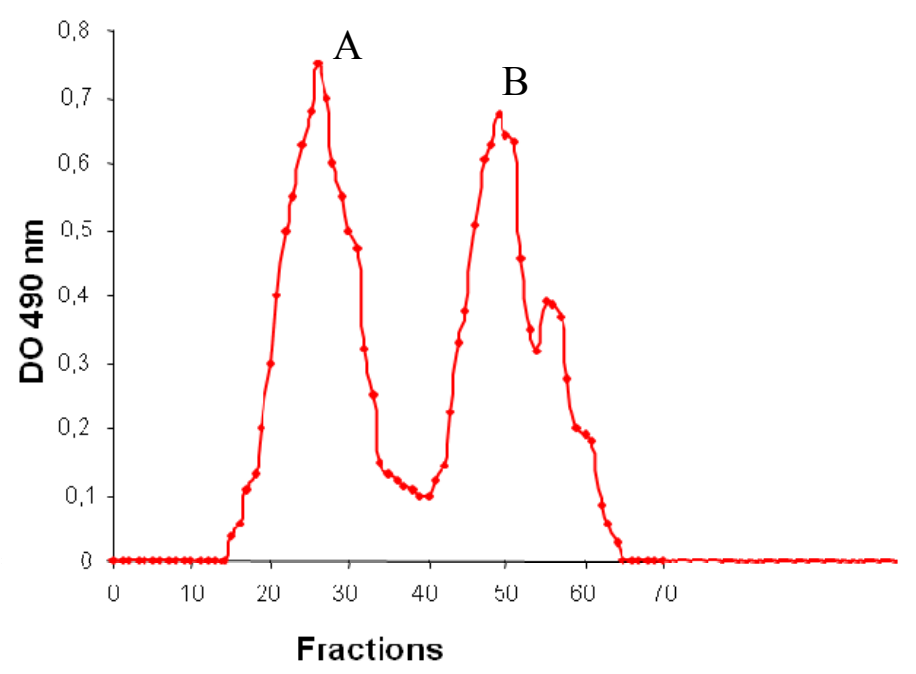

\subsection{Rheological Behaviour of EPS Solutions}

To assess the rheological properties of the EPS we measured the viscosity of its aqueous solutions over a range of different shear rates. The flow curves in Figure 4, show the pseudoplastic character of solutions of the EPS (which includes fractions A and B), their viscosity decreasing concomitantly with shear rate. The exopolysaccharide did not form viscous solutions. 
Figure 4. Viscosity of $0.5 \% \mathrm{w} / \mathrm{v}$ solutions of EPS (fractions $\mathrm{A}$ and B) synthesised by H. almeriensis $\mathrm{M}^{\mathrm{T}}$.

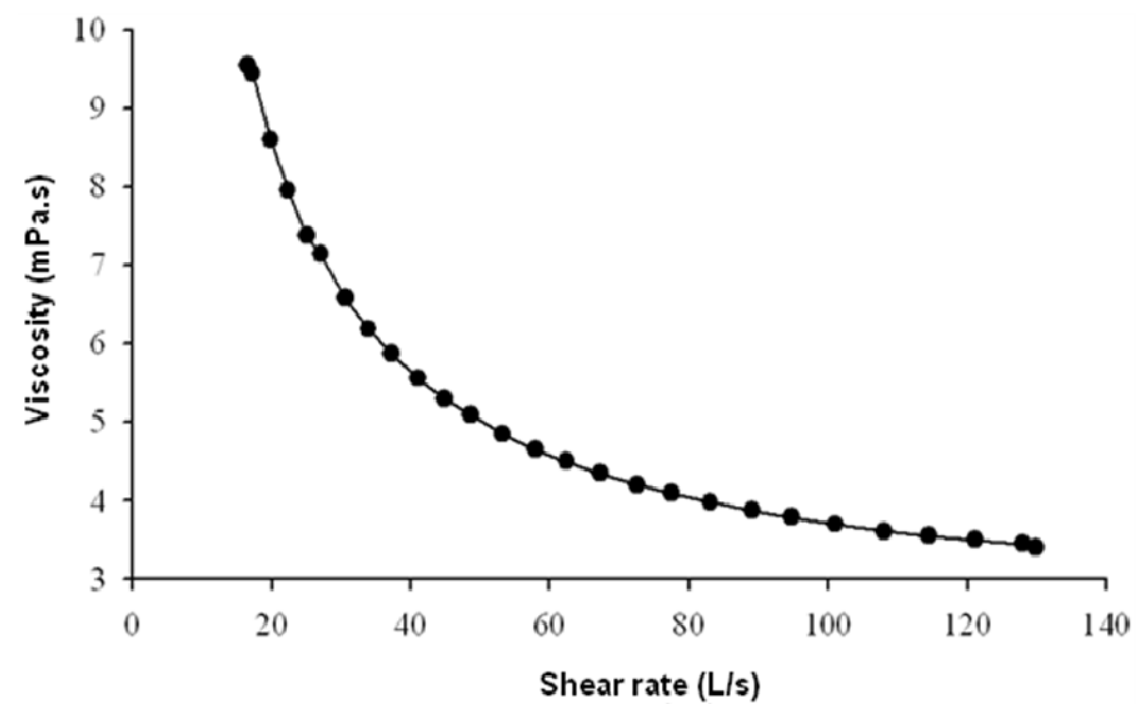

\subsection{Emulsifying Activity}

The emulsifying activity of the EPS (which include fractions A and B) is shown in Table 2. It was capable of stabilising different mixtures of oil and water in which the hydrophobic phase was either a hydrocarbon or a vegetable or mineral oil; its activity was in many cases more efficient than that of any of the surfactants used for comparison. It produced emulsions in which the drops of the oil phase were quite small and uniform in size, below the threshold of $100 \mu \mathrm{m}$ established for fine emulsions. Furthermore, the specific emulsifying activity of Apo-EPSs [containing $0 \% \mathrm{w} / \mathrm{w}$ residual protein] was somewhat lower (about 20-30\%) than that of the native EPS (Table 2), suggesting that its protein content plays a crucial role in its emulsifying capacity.

Table 2. Emulsifying activity of the EPS (fractions A and B) synthesised by H. almeriensis $\mathrm{M} 8^{\mathrm{T}}$.

\begin{tabular}{cccccccc}
\hline \multirow{2}{*}{ EPS origin } & \multicolumn{7}{c}{ Emulsifying activity (\%) * } \\
\cline { 2 - 7 } & Sunflower oil & Mineral oil & Olive oil & Tetradecane & Octane & Kerosene & Isopropil Miristate \\
\hline H. almeriensis & 65 & 67.5 & 67.5 & 62.5 & 65 & 65 & 70 \\
Apo-EPS & 45 & 47.5 & 50 & 46.5 & 42.5 & 45 & 50 \\
Comparisons & & & & & & & 49.9 \\
Sugin 472 & 52.9 & 52.5 & 53.7 & 53.3 & 50 & 49.6 & 67.5 \\
Tween 20 & 62.5 & 57.5 & 60 & 65 & 62.5 & 62 & 60 \\
Tween 80 & 62 & 60 & 61.5 & 60 & 60 & 60 & 65.5 \\
Triton X-100 & 67.5 & 65 & 60 & 65 & 62.5 & 60 & \\
\hline
\end{tabular}

* Expressed as the percentage of the total height occupied by the oil-water emulsion after $24 \mathrm{~h} ; 0.5 \% \mathrm{w} / \mathrm{v}$ EPS or chemical surfactant was used as emulsifier; each value represents the average of three measurements. 


\subsection{Heavy-Metal Uptake}

The polymer produced by $H$. almeriensis strain $\mathrm{M}^{\mathrm{T}}$ under optimum conditions chelated 19.2, 24.5 and $10 \mathrm{mg}$ of copper, lead and cobalt, respectively, per $\mathrm{g}$ of EPS.

\section{Discussion}

We have studied the exopolysaccharide synthesised by $H$. almeriensis strain $\mathrm{M}^{\mathrm{T}}$, a species of moderately halophilic bacterium described previously by our group [13], to determine its potential biotechnological applications. Our results indicate that EPS production by $H$. almeriensis $\mathrm{M}^{\mathrm{T}}$ is on the whole growth-associated, since it is excreted mainly during the exponential growth phase, although it does continue slightly during the subsequent stationary phase. During the exponential growth phase the EPS clings to the cell surface but during the stationary phase it is released into the medium. These results agree with those obtained by our research group for other EPSs produced by halophilic species such as Halomonas maura [25], H. eurihalina [27], H. ventosae and H. anticariensis [32], Idiomarina ramblicola, I. fontislapidosi and Alteromonas hispanica [33] and Salipiger mucescens [34] (Table 3). The culture medium contained the highest quantity of EPS after a period of $120 \mathrm{~h}$, after which it declined, probably due to enzymatic degradation [38]. This also occurs with other microorganisms such as EPS-producing lactic-acid bacteria [38-41], since EPS yields increased during the exponential growth phase and stopped when the stationary growth phase was reached. These results do not agree with those of other authors, however, who maintain that cell growth and EPS formation usually have different nutritional requirements [42-44]. Nevertheless, in our assays the conditions that lead to maximum EPS yield werethe same as those resulting in highest cell growth $(1 \% \mathrm{w} / \mathrm{v}$ glucose as carbon source, $7.5 \% \mathrm{w} / \mathrm{v}$ marine salts, $32{ }^{\circ} \mathrm{C}$ and orbital shaking at $100 \mathrm{rpm}$ ).

The different culture conditions assayed did not change the chemical composition of the EPS although production did decrease significantly when they were unfavourable (data not shown). As the sugar composition of EPSs depends as much on the carbon source [45] as on kinetic and physicalchemical parameters [46], the influence of growth conditions on the monomer composition of the polymer was studied. The results revealed that sugar composition is not influenced by culture growth conditions as we always found the same sugar components at the same relative proportions. Deggest et al. [40] also reported that culturing Lactobacillus sakei 0-1 on different carbon sources did not change the sugar composition of the EPS produced. In the case of H. maura S30, fermentation conditions do not affect the types of sugars in its polysaccharide, but they do influence the monosaccharide ratios [25].

The halophilic bacterial EPSs described until now are normally composed of a single fraction with a molecular mass of between $2 \times 10^{4}$ and $1.9 \times 10^{7}[25,32,33]$, although those synthesised by Idiomarina fontislapidosis and I. ramblicola [32] contain two fractions. Both fractions in the EPS formed by H. almeriensis $\mathrm{M} 8^{\mathrm{T}}$ are within the range of those described previously for EPSs from halophilic bacteria. The low molecular mass of the small fractions, $1.5 \times 10^{4}$, may well explain the low viscosity of its aqueous preparations because the molecular mass distribution of an EPS has a great influence on the rheology of its solutions. 
Table 3. Characteristics of exopolysacharides produced by halophilic bacteria.

\begin{tabular}{|c|c|c|c|c|c|c|c|c|c|c|c|c|c|c|c|c|}
\hline & \multirow[b]{2}{*}{ Strain } & \multirow{2}{*}{$\begin{array}{c}\text { Yield } \\
(\mathrm{g} / 100 \mathrm{~mL})\end{array}$} & \multicolumn{4}{|c|}{ Composition EPS $(\%, w / w)$} & \multirow{2}{*}{$\begin{array}{c}\text { MM } \\
\text { (Daltons) }\end{array}$} & \multicolumn{9}{|c|}{ Monosaccharide $(\%$, w/w) } \\
\hline & & & $\begin{array}{c}\text { Carbohy- } \\
\text { drates } \\
\end{array}$ & Proteins & $\begin{array}{c}\text { Acetyl } \\
\text { residues }\end{array}$ & Sulfate & & Glu & Man & Rha & Gal & Ara & Xyl & Fuc & AGlu & AGal \\
\hline \multicolumn{17}{|l|}{ Halomonas } \\
\hline \multirow{2}{*}{ H. almeriensis } & \multirow{2}{*}{$\mathrm{M} 8^{\mathrm{T}}$} & \multirow{2}{*}{0.17} & \multirow{2}{*}{30.5} & \multirow{2}{*}{1.1} & \multirow{2}{*}{0.8} & \multirow{2}{*}{1.4} & $6.3 \times 10^{6}$ & 27.5 & 72 & 0.5 & ND * & ND & ND & ND & ND & ND \\
\hline & & & & & & & $1.5 \times 10^{4}$ & 30 & 70 & $\mathrm{ND}$ & ND & ND & ND & ND & ND & ND \\
\hline H. maura [25] & S-30 & 0.38 & 65 & 2.5 & 0.18 & 6.5 & $4.7 \times 10^{6}$ & 29 & 35 & ND & 14 & ND & ND & ND & 22 & ND \\
\hline H. eurihalina [27] & F2-7 & 0.14 & 37 & 7.5 & 0.5 & 11.2 & ND & 3.2 & 1 & 1.1 & ND & ND & ND & ND & ND & ND \\
\hline \multirow{2}{*}{ H. ventosae [32] } & $\mathrm{Al}-12^{\mathrm{T}}$ & 0.28 & 30.9 & 2.07 & 1.4 & 1.1 & $5.3 \times 10^{4}$ & 24 & 60 & $\mathrm{ND}$ & 12 & 2 & 4 & $\mathrm{ND}$ & ND & ND \\
\hline & Al-16 & 0.30 & 30.8 & 3.95 & 1.5 & 0.7 & $5.2 \times 10^{4}$ & 24 & 57 & ND & 12 & 3 & 4 & ND & ND & ND \\
\hline \multirow{2}{*}{ H. anticarinesis [32] } & $\mathrm{FP} 35^{\mathrm{T}}$ & 0.29 & 35.5 & 0.3 & 1.55 & 0.75 & $2 \times 10^{4}$ & 15 & 45 & 1.5 & ND & ND & ND & ND & ND & 37 \\
\hline & FP36 & 0.49 & 33.7 & 0.4 & 2.05 & 1.5 & $4.6 \times 10^{4}$ & 17 & 43 & 1.5 & ND & ND & 1.5 & ND & ND & 37.5 \\
\hline \multicolumn{17}{|l|}{ Idiomarina } \\
\hline \multirow{2}{*}{ I. ramblicola [33] } & \multirow{2}{*}{$\mathrm{R}-22^{\mathrm{T}}$} & \multirow{2}{*}{0.15} & \multirow{2}{*}{56.5} & \multirow{2}{*}{0.8} & \multirow{2}{*}{1.15} & \multirow{2}{*}{0.5} & $5.5 \times 10^{5}$ & 2 & 68 & 7 & ND & ND & ND & ND & ND & ND \\
\hline & & & & & & & $2 \times 10^{4}$ & 19 & 54 & $\mathrm{ND}$ & ND & ND & ND & ND & ND & 26 \\
\hline \multirow{2}{*}{ I. fontislapidosi [33] } & \multirow{2}{*}{$\mathrm{F}-23^{\mathrm{T}}$} & \multirow{2}{*}{0.14} & \multirow{2}{*}{50.85} & \multirow{2}{*}{0.8} & \multirow{2}{*}{1.85} & \multirow{2}{*}{0.65} & $1.5 \times 10^{6}$ & 28 & 46 & ND & 15 & 3 & 5 & 2 & ND & ND \\
\hline & & & & & & & $1.5 \times 10^{4}$ & 40 & 60 & $\mathrm{ND}$ & 20 & ND & ND & $\mathrm{ND}$ & ND & ND \\
\hline $\begin{array}{c}\text { Alteromonas } \\
\text { hispanica }[33]\end{array}$ & $\mathrm{F} 32^{\mathrm{T}}$ & 0.1 & 0.25 & 4.3 & 0.25 & 0.25 & $1.9 \times 10^{7}$ & 18 & 63 & ND & ND & ND & 12 & ND & ND & ND \\
\hline $\begin{array}{c}\text { Salipiger } \\
\text { mucescens }[34]\end{array}$ & $\mathrm{A} 3^{\mathrm{T}}$ & 0.16 & 53.15 & 1.65 & 0.9 & 0.95 & $2.5 \times 10^{5}$ & 20 & 34 & ND & 33 & ND & ND & 13 & ND & ND \\
\hline
\end{tabular}

Glu: glucose; Man: mannose; Rha: rhamnose, Gal: galactose; Ara: arabinose; Xyl: xylose; Fuc: fucose; AGlu: glucuronic acid; AGal: galacturonic acid; MM: molecular mass. * ND: Not detected. 
The sulphate and phosphate contents of the EPS produced by $H$. almeriensis $\mathrm{M}^{\mathrm{T}}$ are especially interesting. The majority of EPSs with biomedical properties contain sulphate groups and evidence suggests that this is a critical feature as far as these properties are concerned [47]. For instance, both EPS-1 and EPS-2 produced by Alteromonas infernus are biologically inert in their native state, their potent biomedical capacity resulting from chemical over-sulphation [48]. Other sulphated EPSs have many clinical applications as anticoagulant and antithrombotic [49], anti-atherosclerotic [50], antiproliferative [51], anti-angiogenic [52], antimetastatic [53], anti-inflammatory [54], complementinhibiting [55] and antiviral [56] agents. Among the EPSs from halophilic bacteria, we have in the past studied the sulphated EPS from $H$. eurihalina H2-7, which enhances the unspecific proliferation of human lymphocytes in response to the presence of the anti-CD3 mononuclear antibody [57], and the sulphated EPSs from Halomonas stenophila (B100 and N12 ${ }^{\mathrm{T}}$ [18], which blocks the growth of human T-lymphocyte tumours [58].

Phosphate groups, which have also been observed in other EPSs from halophilic bacteria [33], could also confer important properties on them because they are required for the activation of lymphocytes [59] and in some antitumoural processes [60].

Proteins play an essential role in the emulsifying capacity of some polysaccharides $[33,61,62]$. The results of protein electrophoresis and Bradford's assay seem to confirm that the EPS deriving from H. almeriensis $\mathrm{M} 8^{\mathrm{T}}$ contains a substantial protein fraction, and chemical deproteinization indicates that the protein content plays an important role in its emulsifying capacity, just as it does with the polymers produced by $H$. ventosae and $H$. anticariensis [33]. Furthermore, the molecular mass of the protein detected in our EPS (about $45 \mathrm{kDa}$ ) is similar to that obtained for the active component of the bio-emulsifier alasan, produced by Acinetobacter radioresistens KA53 [63]. Whatever the reason, the emulsions produced by our polymer have low viscosity, are stable and are composed of small, uniform droplets, resulting in a fine, smooth consistency, so it could well be used as an emulsifying agent in the food and oil industries, where emulsifiers from microbial sources have attracted attention because of the advantages they offer over artificial products [64]. Emulsifying agents are also called for in medical sciences [65]. Other known EPSs, such as xanthan, are capable of forming stable emulsions but they tend to be thicker and more viscous, which is not very desirable for some of the uses for which emulsifiers such as these are intended [66].

Rapid industrialization and increasing urbanization are contaminating our environment by discharging heavy metals in effluents, with all the consequent damage to health and the environment which this implies. Remediation of the situation with currently used physical-chemical techniques is expensive and can cause even further environmental harm. Hence, biotechnological approaches have received a great deal of attention in recent years as an alternative approach to the problem of metal pollution. The need for safe, effective, economical methods for removing heavy metals from polluted environments and wastewater has directed attention to EPSs produced by algae, bacteria, fungi and yeasts [67]. The adsorption of heavy metal onto EPSs is caused by interaction between metal ions and the negative charges of functional acid groups of the EPSs and is a non-metabolic, energy-independent process [68]. Bearing this in mind we studied the possibility of using the EPS produced by $H$. almeriensis to chelate copper, lead and cobalt. Anionic EPSs prefer on the whole to bind cations with large ionic radii [50], which agrees with our findings, since our polymer bound lead most efficiently, as we have previously reported for mauran [25] and the EPS produced by strain $\mathrm{A} 112^{\mathrm{T}}$ of 
$H$. ventosae [33]. It may well be that acetyls bring more electron-donating groups into the vicinity of the binding site, thus allowing the larger $\mathrm{Pb}$ ions to bind more strongly [50]. Nevertheless, the EPS from $H$. almeriensis $\mathrm{M}^{\mathrm{T}}$ chelated a considerable quantity of cobalt (10 mg/g EPS), whilst mauran [25] and the EPS produced by Enterobacter cloacae [67] could only chelate small quantities of cobalt. Although we are not yet sure of the precise mechanism involved when ions bind to these polymers, this type of chelation could be classified as biosorption, as mentioned by Valls and de Lorenzo [69]. Whatever the case may be, the strong chelating property of these polymers offers the possibility of their being used as a biosorbent in water treatment and to clean polluted environments.

\section{Experimental}

\subsection{Microorganism and Culture Media}

We cultured H. almeriensis strain $\mathrm{M}^{\mathrm{T}}\left(=\mathrm{CECT} 7050^{\mathrm{T}}\right)$, isolated from a soil sample from Cabo de Gata, Almería, Spain [13]. The culture medium used both for EPS extraction and for maintaining the bacterial strain was MY complex medium [70] supplemented with 7.5\% w/v sea-salts [71]. The $\mathrm{pH}$ was adjusted to 7.2 and the medium sterilized by heating to $112^{\circ} \mathrm{C}$ for $30 \mathrm{~min}$.

\subsection{EPS Production}

In experiments conducted in a previous work [13] we ascertained that the optimum conditions for the growth of $H$. almeriensis strain $\mathrm{M}^{\mathrm{T}}$ were incubation in $\mathrm{MY}$ medium containing $7.5 \% \mathrm{w} / \mathrm{v}$ total salts and an initial glucose concentration of $1 \% \mathrm{w} / \mathrm{v}$ at $32{ }^{\circ} \mathrm{C}$, with orbital shaking at $100 \mathrm{rpm}$ and an initial $\mathrm{pH}$ of 7.0. On the basis of these initial findings we have undertaken further experiments to monitor bacterial growth and EPS production versus temperature $\left(22,32\right.$ and $\left.42{ }^{\circ} \mathrm{C}\right)$, shaking $(0,100$ and $200 \mathrm{rpm})$, total sea-salts $(2.5,5,7.5$ and $10 \% \mathrm{w} / \mathrm{v})$, glucose concentration $(0,1,2,5,7$ and $10 \% \mathrm{w} / \mathrm{v})$ and sucrose, mannose and galactose as alternative carbon sources. EPS production was determined after its separation from the culture medium using the method described in a previous work [27]. Briefly, the culture was centrifuged and the supernatant precipitated with cold ethanol before being ultracentrifuged, dialyzed against distilled water and lyophilized. Bacterial growth was determined by measuring optical density at $600 \mathrm{~nm}$. Any residual glucose was calculated using the glucose-oxidase technique [72].

\subsection{Chemical Analysis and Determination of Molecular Mass}

We made the following colorimetric analyses: total carbohydrates [73], proteins [74], acetyl residues [75], pyruvate [76] and hexosamines [77]. Sulphate and phosphate contents were analysed using a Dionex DX-100 (Idstein, Germany) gradient chromatography system with chemical suppression of eluent conductivity. The eluent was $1.7 \mathrm{mM} \mathrm{Na} \mathrm{CO}_{3} / \mathrm{NaHCO}_{3}$. We used $35 \mathrm{mM} \mathrm{H}_{2} \mathrm{SO}_{4}$ as acid regenerant.

The EPS was purified and its negative net charge analysed by anion-exchange chromatography (AEC) (Rockford, IL, USA) on a $1.5 \mathrm{~m} \times 20 \mathrm{~cm}$, quaternary methyl ammonium (QMA) Accel Plus column (Waters, Kent, UK). The column was eluted at a flow rate of $2 \mathrm{~mL} / \mathrm{min}$ with $0.05 \mathrm{M}$ $\mathrm{NH}_{4} \mathrm{HCO}_{3}(\mathrm{pH} 8.0)$ followed by a linear gradient of 0.05 to $2 \mathrm{M} \mathrm{NaCl}$ in the same buffer. The EPS was 
monitored by UV detection at $210 \mathrm{~nm}$. 5-mL fractions were collected to determine their sugar composition and molecular mass.

Monosaccharides were analysed using myo-inositol as internal standard. $100-\mu \mathrm{g}$ equivalents of total carbohydrates of purified EPS were subjected to methanolysis with methanolic $\mathrm{HCl} 0.9 \mathrm{M}$, for $16 \mathrm{~h}$ at $80{ }^{\circ} \mathrm{C}$. The resulting mixture of methylglycosides was dried under nitrogen at room temperature and re-N-acetylated by the addition of $50 \mu \mathrm{L}$ of dry methanol, $5 \mu \mathrm{L}$ of pyridine and $5 \mu \mathrm{L}$ of acetic anhydride [78]. After drying and derivation with $15 \mu \mathrm{L}$ trimethylsilylimidazole (TMSIM, Alltech, (Eke, Belgium) at room temperature for $30 \mathrm{~min}$, the re-N-acetylated trimethylsilylated glycosides were analysed on a $30 \mathrm{~m} \times 0.32 \mathrm{~mm}$ PTE 5 fused-silica capillary column (Supelco, Bellefonte, PA, USA) with an 8060/MD 800 GLC-mass spectrometry (GLC-MS) system (Fisons Instruments, Interscience, Breda, The Netherlands). Before analysis on the GLC-MS system the TMS samples were dried under nitrogen and dissolved in $500 \mu \mathrm{L}$ hexane; $1 \mu \mathrm{L}$ was then injected using a splitless injector. The oven program included an initial temperature of $80^{\circ} \mathrm{C}$ for $2 \mathrm{~min}$ followed by an increase to $235^{\circ} \mathrm{C}$ at a rate of $20^{\circ} \mathrm{C} / \mathrm{min}$ before being held at $235^{\circ} \mathrm{C}$ for $2 \mathrm{~min}$.

Apparent molecular mass was determined by high-performance size-exclusion chromatography (HPSEC) performed on a 600E system (Waters) equipped with a $30 \mathrm{~cm} \times 7.5 \mathrm{~mm}$ PL aquagel-OH 60 $8 \mu \mathrm{m}$ column (Polymer Laboratories, Shropshire, UK) eluted with a $0.2 \mathrm{M}$ sodium-acetate buffer (pH 5.1) at a flow rate of $0.8 \mathrm{~mL} / \mathrm{min}$. The sample volume was $20 \mu \mathrm{L}$, containing $25 \mu \mathrm{g}$ of purified EPS. Compounds were detected using refractive-index monitoring (Model 475, Kontron Instruments, Schlieren, Switzerland) and standard dextrans were used to determine molecular masses.

\subsection{Rheological Analysis}

The EPS was dissolved in distilled water $(0.5 \% \mathrm{w} / \mathrm{v})$ and rheological measurements were made at $25{ }^{\circ} \mathrm{C}$ in a controlled-stress Bohlin CSR10 rheometer (Gloucestershire, UK).

\subsection{Emulsifying Activity}

Emulsification assays were conducted according to Cooper and Goldenberg [79]. The EPS was dissolved in $5 \mathrm{~mL}$ of distilled water $(0.5 \% \mathrm{w} / \mathrm{v})$ and mixed in test tubes $(105 \times 15 \mathrm{~mm})$ with $5 \mathrm{~mL}$ of each hydrophobic substrate before being vortexed to homogeneity and left to stand for $24 \mathrm{~h}$ at $25{ }^{\circ} \mathrm{C}$. Emulsifying activity was expressed as the percentage of the total height occupied by the emulsion after $24 \mathrm{~h}$. The hydrophobic substrates were commercial brands of sunflower and olive oils, mineral oil, tetradecane, octane (Sigma, Madrid, Spain), kerosene (Panreac, Barcelona, Spain) and isopropyl myristate (Gley de Brech Inc., Granada, Spain). Sugin 472, Tween 20, Tween 80 and Triton X-100 (Sigma) were used as comparative chemical surfactants. The emulsions were observed under a light microscope to determine the size and uniformity of the drops in the oil phase and whether or not there was creaming or flocculation.

Native EPS from $H$. almeriensis was chemically deproteinized to find out whether the protein fraction had any influence on its emulsifying power. The polymer was then analysed by protein electrophoresis and Bradford colorimetric analysis [74]. Finally the emulsification assays were repeated with the chemically deproteinized EPS (Apo-EPS). Apo-EPS was obtained by the hot-phenol method [80], which entailed heating $500 \mathrm{mg}$ of EPS in $100 \mathrm{~mL}$ of water to $70{ }^{\circ} \mathrm{C}$ and then stirring with 
an equal volume of preheated $90 \% \mathrm{v} / \mathrm{v}$ phenol in water for $15 \mathrm{~min}$ before cooling to $0{ }^{\circ} \mathrm{C}$ and finally centrifuging. The lower (phenol) phase was stirred with an equal volume of water and then centrifuged. The combined aqueous phases were dialyzed against distilled water and lyophilized. The white, fluffy material was termed Apo-EPS. SDS-PAGE was carried out by the method of Laemmli [81] to study the presence of any proteins in the EPS. Samples were dissolved in $2 \% \mathrm{w} / \mathrm{v}$ SDS, $4 \% \mathrm{w} / \mathrm{v}$ $\beta$-mercaptoethanol, $8 \% \mathrm{w} / \mathrm{v}$ glycerol, $50 \mathrm{mM}$ Tris- $\mathrm{HCl}(\mathrm{pH} 6.8)$ and $0.02 \% \mathrm{w} / \mathrm{v}$ bromphenyl blue and then heated to $100{ }^{\circ} \mathrm{C}$ for $10 \mathrm{~min}$. Prestained broad-range SDS-PAGE standards (Bio-Rad Co., Hercules, CA, USA) were used as molecular mass markers. The running buffer was $0.1 \% \mathrm{w} / \mathrm{v}$ SDS, $192 \mathrm{mM}$ glycine, and $25 \mathrm{mM}$ Tris- $\mathrm{HCl}$ (pH 8.3). Gels were stained with Coomassie brilliant blue.

\subsection{Heavy-Metal Binding Capacity}

Metal-binding analyses were undertaken as described by Geddie and Sutherland [82]. The EPS was applied to an Amberlite IR $120 \mathrm{H}^{+}$cation-exchange column (Avocado) buffered with bi-distilled water to convert it into the acidic form. EPS solutions $(0.5 \% \mathrm{w} / \mathrm{v}, 5 \mathrm{~mL})$ were put into dialysis tubing in flasks containing copper sulphate, cobalt chloride or lead acetate (Sigma, $200 \mathrm{~mL}$ ) and shaken at $100 \mathrm{rpm}$ for $24 \mathrm{~h}\left(30^{\circ} \mathrm{C}\right)$. The quantity of metal removed from the solution (i.e., that bound to the EPS) was calculated by measuring by atomic absorption spectrophotometry the ions in solution at $0 \mathrm{~h}$ and those remaining after $24 \mathrm{~h}$. Controls were made by placing $5 \mathrm{~mL}$ of distilled water in dialysis tubing with the various metal-salt solutions.

\subsection{Electron Microscopy}

Ultrathin sections of bacterial cells were negatively stained as described elsewhere [10].

\section{Conclusions}

H. almeriensis $\mathrm{M} 8^{\mathrm{T}}$ synthesised significant quantities of exopolysaccharide when cultivated under optimum growth conditions and this EPS has properties that render it suitable for application as a biological agent, bio-detoxifier and emulsifier.

\section{Acknowledgments}

The authors are grateful to R. Tallón, P. Bressollier and M.C. Urdaci for their help with the chemical studies, and to Concepción Hernández and David Porcel for their expertise in microscope studies. This research was supported by grants from the Dirección General de Investigación Científica y Técnica BOS 2003-00498; CGL2005-05947; CGL2008-02399; BIO2011-2013 and by grants from the Plan Andaluz de Investigación PO6-CVI-01850. They also thank their colleague J. Trout for revising our English text.

\section{References and Notes}

1. Sutherland, I.W. Biotechnology of Microbial Exopolysaccharides; Cambridge University Press: New York, NY, USA, 1990. 
2. Sutherland, I.W. Biofilm exopolysaccharides: A strong and sticky framework. Microbiology 2001, 147, 3-9.

3. Sutherland, I.W. Microbial polysaccharides from Gram-negative bacteria. Int. Dairy J. 2001, 11, 663-674.

4. Freitas, F.; Alves, V.D.; Reis, M.A. Advances in bacterial exopolysaccharides: From production to biotechnological applications. Trends Biotechnol. 2011, 29, 388-398.

5. Wolfaardt, G.M.; Lawrence, J.R.; Korber, D.R. Functions of EPS. In Microbial Extracelullar Polymeric Substances; Wingender, J., Neu, T.R., Flemming, H.C., Eds.; Sringer-Verlag: Berlin, Germany, 1999; pp. 171-200.

6. Sutherland, I.W. Structure-function relationships in microbial exopolysaccharides. Biotechnol. Adv. 1994, 12, 393-448.

7. Sutherland, I.W. Polysaccharides from Microorganisms, Plants and Animals. In Biopolymers, Polysaccharides I. Polysaccharides from Prokaryotes; Vandamme, E.J., De Baets, S., Steinbüchel, A., Eds; Wiley: Weinheim, Germany, 2002; pp. 1-19.

8. Quesada, E.; Valderrama, M.J.; Béjar, V.; Ventosa, A.; Gutierrez, M.C.; Ruiz-Berraquero, F.; Ramos-Cormenzana, A. Volcaniella eurihalina gen nov., sp. nov., a moderately halophilic nonmotile gram-negative rod. Int. J. Syst. Bacteriol. 1990, 40, 261-267.

9. Shea, C.; Nunley, J.W.; Williamson, J.C.; Smith-Somerville, H.E. Comparison of the adhesion properties of Deleya marina and the exopolysaccharide-defective mutant strain DMR. Appl. Environ. Microbiol. 1995, 57, 3107-3113.

10. Bouchotroch, S.; Quesada, E.; del Moral, A.; Llamas, I.; Béjar, V. Halomonas maura sp. nov., a novel moderately halophilic, exopolysaccharide-producing bacterium. Int. J. Syst. Evol. Microbiol. 2001, 51, 1625-1632.

11. Martínez-Cánovas, M.J.; Béjar, V.; Martínez-Checa, F.; Quesada, E. Halomonas anticariensis sp. nov., from Fuente de Piedra, a saline-wetland wildfowl reserve in Malaga, southern Spain. Int. J. Syst. Evol. Microbiol. 2004, 54, 1329-1332.

12. Martínez-Cánovas, M.J.; Quesada, E.; Llamas, I.; Béjar, V. Halomonas ventosae sp. nov., a moderately halophilic, denitrifying, exopolysaccharide-producing bacterium. Int. J. Syst. Evol. Microbiol. 2004, 54, 733-737.

13. Martínez-Checa, F.; Béjar, V.; Martínez-Cánovas, M.J.; Llamas, I.; Quesada, E. Halomonas almeriensis sp. nov., a moderately halophilic, exopolysaccharide-producing bacterium from Cabo de Gata, Almeria, south-east Spain. Int. J. Syst. Evol. Microbiol. 2005, 55, 2007-2011.

14. González-Domenech, C.M.; Béjar, V.; Martínez-Checa, F.; Quesada, E. Halomonas nitroreducens sp. nov., a novel nitrate- and nitrite-reducing species. Int. J. Syst. Evol. Microbiol. 2008, 58, 872-876.

15. González-Domenech, C.M.; Martínez-Checa, F.; Quesada, E.; Béjar, V. Halomonas cerina sp. nov., a moderately halophilic, denitrifying, exopolysaccharide-producing bacterium. Int. J. Syst. Evol. Microbiol. 2008, 58, 803-809.

16. González-Domenech, C.M.; Martínez-Checa, F.; Quesada, E.; Béjar, V. Halomonas fontilapidosi sp. nov., a moderately halophilic, denitrifying bacterium. Int. J. Syst. Evol. Microbiol. 2009, 59, 1290-1296. 
17. Amjres, H.; Béjar, V.; Quesada, E.; Abrini, J.; Llamas, I. Halomonas rifensis sp. nov., an exopolysaccharide-producing, halophilic bacterium isolated from a solar saltern. Int. J. Syst. Evol. Microbiol. 2011, 61, 2600-2605.

18. Llamas, I.; Béjar, V.; Martínez-Checa, F.; Martínez-Cánovas, M.J.; Molina, I.; Quesada, E. Halomonas stenophila sp. nov., a halophilic bacterium that produces sulphate exopolysaccharides with biological activity. Int. J. Syst. Evol. Microbiol. 2011, 61, 2508-2514.

19. Martínez-Cánovas, M.J.; Béjar, V.; Martínez-Checa, F.; Paez, R.; Quesada, E. Idiomarina fontislapidosi sp. nov. and Idiomarina ramblicola sp. nov., isolated from inland hypersaline habitats in Spain. Int. J. Syst. Evol. Microbiol. 2004, 54, 1793-1797.

20. Martínez-Checa, F.; Béjar, V.; Llamas, I.; Del Moral, A.; Quesada, E. Alteromonas hispanica sp. nov., a polyunsaturated-fatty-acid-producing, halophilic bacterium isolated from Fuente de Piedra, southern Spain. Int. J. Syst. Evol. Microbiol. 2005, 55, 2385-2390.

21. Martínez-Cánovas, M.J.; Quesada, E.; Martínez-Checa, F.; Del Moral, A.; Béjar, V. Salipiger mucescens gen. nov., sp. nov., a moderately halophilic, exopolysaccharide-producing bacterium isolated from hypersaline soil, belonging to the alpha-Proteobacteria. Int. J. Syst. Evol. Microbiol. 2004, 54, 1735-1740.

22. Martínez-Checa, F.; Quesada, E.; Martínez-Cánovas, M.J.; Llamas, I.; Béjar, V. Palleronia marisminoris gen. nov., sp. nov., a moderately halophilic, exopolysaccharide-producing bacterium belonging to the 'Alphaproteobacteria', isolated from a saline soil. Int. J. Syst. Evol. Microbiol. 2005, 55, 2525-2530.

23. Oren, A. Industrial and environmental applications of halophilic microorganisms. Environ. Technol. 2010, 31, 825-834.

24. Bouchotroch, S.; Quesada, E.; Izquierdo, I.; Rodríguez, M.; Béjar, V. Bacterial exopolysaccharides produced by new discovered bacteria belonging to the genus Halomonas isolated from hypersaline habitats in Morocco. J. Ind. Microbiol. Biotechnol. 2000, 24, 374-378.

25. Arias, S.; del Moral, A.; Ferrer, M.R.; Tallón, R.; Quesada, E.; Béjar, V. Mauran, an exopolysaccharide produced by the halophilic bacterium Halomonas maura, with a novel composition and interesting properties for biotechnology. Extremophiles 2003, 7, 319-326.

26. Quesada, E.; Béjar, V.; Ferrer, M.R.; Calvo, C.; Llamas, I.; Martínez-Checa, F.; Arias, S.; Ruiz-García, C.; Páez, R.; Martínez-Cánovas, M.J.; et al. Moderately Halophilic Exopolysaccharide-Producing Bacteria. In Halophilic Microorganisms; Ventosa, A., Ed.; Springer: Berlin, Germany, 2004.

27. Quesada, E.; Béjar, V.; Calvo, C. Exopolysaccharide production by Volcaniella eurihalina. Experientia 1993, 49, 1037-1041.

28. Calvo, C.; Ferrer, M.R.; Martínez-Checa, F.; Béjar, V.; Quesada, E. Some rheological properties of the extracellular polysaccharide produced by Volcaniella eurihalina F2-7. Appl. Biochem. Biotechnol. 1995, 55, 45-54.

29. Béjar, V.; Calvo, C.; Moliz, J.; Diaz-Martínez, F.; Quesada, E. Effect of growth conditions on the rheologial properties and chemical composition of Volcaniella eurihalina exopolysaccharide. Appl. Biochem. Biotechnol. 1996, 59, 77-85.

30. Béjar, V.; Llamas, I.; Calvo, C.; Quesada, E. Characterization of exopolysaccharides produced by 19 halophilic strains of the species Halomonas eurihalina. J. Biotechnol. 1998, 61, 135-141. 
31. Calvo, C.; Martínez-Checa, F.; Mota, A.; Béjar, V.; Quesada, E. Effect of cations, pH and sulfate content on the viscosity and emulsifyng activity of the Halomonas eurihalina exopolysaccharide. J. Ind. Microbiol. Biotechnol. 1998, 20, 205-209.

32. Mata, J.A.; Béjar, V.; Llamas, I.; Arias, S.; Bressollier, P.; Tallon, R.; Urdaci, M.C.; Quesada, E. Exopolysaccharides produced by the recently described bacteria Halomonas ventosae and Halomonas anticariensis. Res. Microbiol. 2006, 157, 827-835.

33. Mata, J.A.; Béjar, V.; Bressollier, P.; Tallon, R.; Urdaci, M.C.; Quesada, E.; Llamas, I. Characterization of exopolysaccharides produced by three moderately halophilic bacteria belonging to the family Alteromonadaceae. J. Appl. Microbiol. 2008, 105, 521-528.

34. Llamas, I.; Mata, J.A.; Tallon, R.; Bressollier, P.; Urdaci, M.C.; Quesada, E.; Béjar, V. Characterization of the exopolysaccharide produced by Salipiger mucosus A3, a halophilic species belonging to the Alphaproteobacteria, isolated on the Spanish Mediterranean seaboard. Mar. Drugs 2010, 8, 2240-2251.

35. Antón, J.; Meseguer, I.; Rodríguez-Valera, F. Production of an Extracellular Polysaccharide by Haloferax mediterranei. Appl. Environ. Microbiol. 1988, 54, 2381-2386.

36. Parolis, H.; Parolis, L.A.; Boan, I.F.; Rodriguez-Valera, F.; Widmalm, G.; Manca, M.C.; Jansson, P.E.; Sutherland, I.W. The structure of the exopolysaccharide produced by the halophilic Archaeon Haloferax mediterranei strain R4 (ATCC 33500). Carbohydr. Res. 1996, 295, 147-156.

37. Nicolaus, B.; Schiano, M.; Lama, L.; Poli, A.; Gambacorta, A. Polysaccharides from extremophilic microorganisms. Orig. Life Evol. Biosph. 2004, 34, 159-169.

38. Pham, P.L.; Dupont, I.; Roy, D.; Lapointe, G.; Cerning, J. Production of exopolysaccharide by Lactobacillus rhamnosus $\mathrm{R}$ and analysis of its enzymatic degradation during prolonged fermentation. Appl. Environ. Microbiol. 2000, 66, 2302-2310.

39. Torino, M.I.; Mozzi, F.; Sesma, F.; Font de Valdez, G. Semidefined media for the exopolysaccharide (EPS) production by Lactobacillus helveticus ATCC 15807 and evaluation of the components interfering with the EPS quantification. Milchwissenschaft 2000, 55, 314-316.

40. Degeest, B.; Janssens, B.; De Vuyst, L. Exopolysaccharide (EPS) biosynthesis by Lactobacillus sakei 0-1: Production kinetics, enzyme activities and EPS yields. J. Appl. Microbiol. 2001, 91, 470-477.

41. Tallon, R.; Bressollier, P.; Urdaci, M. Isolation and characterization of two exopolysaccharides produced by Lactobacillus plantarum EP56. Res. Microbiol. 2003, 154, 705-712.

42. Petronella, J.L.; Hugenholtz, J. Uncoupling of growth and exopolysaccharide production by Lactococcus lactis subsp. cremoris NIZO B40 and optimization of its synthesis. J. Biosci. Bioeng. 1999, 88, 178-182.

43. Cheirslip, B.; Shimizu, H.; Shioya, S. Modelling and optimization of environmental conditions for kefiran production by Lactobacillus kefiranofaciens. Appl. Microbiol. Biotechnol. 2001, 57, 639-643.

44. Gorret, A.U.; Maubois, N.; Engasser, J.L.; Ghoul, J.M. Study of the effects of temperature, $\mathrm{pH}$ and yeast extract on growth and exopolysaccharide production by Propionibacterium acidipropionici on milk microfiltrate using a response surface methodology. J. Appl. Microbiol. 2001, 90, 788-796. 
45. Kojic, M.; Vujcic, M.; Banina, A.; Cocconcelli, P.; Cerning, J.; Topisirovic, L. Analysis of exopolysaccharide production by Lactobacillus casei CG11, isolated from cheese. Appl. Environ. Microbiol. 1992, 58, 4086-4088.

46. Grobben, G.J.; Sikkema, J.; Smith, M.R.; de Bont, J.A.M. Production of extracellular polysaccharides by Lactobacillus delbrueckii NCFB 2772 grown in a chemically defined medium. J. Appl. Bacteriol. 1995, 79, 103-107.

47. Wu, X.Z.; Chen, D. Effects of sulfated polysaccharides on tumour biology. West Indian Med. J. 2006, 55, 270-273.

48. Colliec, J.S.; Chevolot, L.; Helley, D.; Ratiskol, J.; Bros, A.; Sinquin, C.; Roger, O.; Fischer, A.M. Characterization, chemical modifications and in vitro anticoagulant properties of an exopolysaccharide produced by Alteromonas infernus. Biochim. Biophys. Acta 2001, 1528, 141-151.

49. Ciancia, M.; Quintana, I.; Cerezo, A.S. Overview of anticoagulant activity of sulfated polysaccharides from seaweeds in relation to their structures, focusing on those of green seaweeds. Curr. Med. Chem. 2010, 17, 2503-2529.

50. Engelberg, H. Heparin, non-heparin glycosaminoglycans, and heparinoids: an overview of their application in atherosclerosis. Semin. Thromb. Hemost. 1991, 17, 5-8.

51. Logeart, D.; Prigent-Richard, S.; Boisson-Vidal, C.; Chaubet, F.; Durand, P.; Jozefonvicz, J.; Letourneur, D. Fucans, sulfated polysaccharides extracted from brown seaweeds, inhibit vascular smooth muscle cell proliferation. II. Degradation and molecular weight effect. Eur. J. Cell Biol. 1997, 74, 385-390.

52. Ganesan, P.; Matsubara, K.; Ohkubo, T.; Tanaka, Y.; Noda, K.; Sugawara, T.; Hirata, T. Anti-angiogenic effect of siphonaxanthin from green alga, Codium fragile. Phytomedicine 2010, 17, 1140-1144.

53. Parish, C.R.; Coombe, D.R.; Jakobsen, K.B.; Bennett, F.A.; Underwood, P.A. Evidence that sulphated polysaccharides inhibit tumour metastasis by blocking tumour-cell-derived heparanases. Int. J. Cancer 1987, 40, 511-518.

54. Matsui, M.S.; Muizzuddin, N.; Arad, S.; Marenus, K. Sulfated polysaccharides from red microalgae have antiinflammatory properties in vitro and in vivo. Appl. Biochem. Biotechnol. 2003, 104, 13-22.

55. Blondin, C.; Fischer, E.; Boisson-Vidal, C.; Kazatchkine, M.D.; Jozefonvicz, J. Inhibition of complement activation by natural sulfated polysaccharides (fucans) from brown seaweed. Mol. Immunol. 1994, 31, 247-253.

56. Ghosh, T.; Chattopadhyay, K.; Marschall, M.; Karmakar, P.; Mandal, P.; Ray, B. Focus on antivirally active sulfated polysaccharides: From structure-activity analysis to clinical evaluation. Glycobiology 2009, 19, 2-15.

57. Pérez-Fernández, M.E.; Quesada, E.; Gálvez, J.; Ruíz, C. Effect of exopolysaccharide V2-7 isolated from Halomonas eurihalina on the proliferation in vitro of human peripheral blood lymphocites. Immunopharmacol. Immunotoxicol. 2000, 22, 131-141.

58. Ruiz-Ruiz, C.; Srivastava, G.K.; Carranza, D.; Mata, J.A.; Llamas, I.; Santamaria, M.; Quesada, E.; Molina, I.J. An exopolysaccharide produced by the novel halophilic bacterium Halomonas stenophila strain B100 selectively induces apoptosis in human T leukaemia cells. Appl. Microbiol. Biotechnol. 2011, 89, 345-355. 
59. Nishimura-Uemura, J.; Kitazawa, H.; Kawai, Y.; Itoh, T.; Oda, M.; Saito, T. Functional alteration of murine macrophages stimulated with extracellular polysaccharides from Lactobacillus delbrueckii ssp. bulgaricus OLL1073R-1. Food Microbiol. 2003, 20, 267-273.

60. Ebina, T.; Ogata, N.; Murata, K. Antitumor effect of Lactobacillus bulgaricus 878R. Biotherapy 1995, 9, 65-70.

61. Rosenberg, E.; Zuckerberg, A.; Rubinovitz, C.; Gutnick, D.L. Emulsifier of Arthrobacter RAG-1: Isolation and emulsifying properties. Appl. Environ. Microbiol. 1979, 37, 402-408.

62. Navon-Venezia, S.; Banin, E.; Ron, E.Z.; Rosenberg, E. The bioemulsifier alasan: Role of protein in maintaining structure and activity. Appl. Microbiol. Biotechnol. 1998, 49, 382-384.

63. Toren, A.; Orr, E.; Paitan, Y.; Ron, E.Z.; Rosenberg, E. The active component of the bioemulsifier alasan from Acinetobacter radioresistant KA53 is an OmpA-like protein. J. Bacteriol. 2002, 184, 165-170.

64. Banat, I.M.; Makkar, R.S.; Cameotra, S.S. Potential commercial applications of microbial surfactants. Appl. Microbiol. Biotechnol. 2000, 53, 495-508.

65. Singh, P.; Cameotra, S.S. Potential applications of microbial surfactants in biomedical sciences. Trends Biotechnol. 2004, 22, 142-146.

66. Desai, J.D.; Banat, I.M. Microbial production of surfactants and their commercial potential. Microbiol. Mol. Biol. Rev. 1997, 61, 47-64.

67. Iyer, A.; Mody, K.; Jha, B. Biosorption of heavy metals by a marine bacterium. Mar. Pollut. Bull. 2005, 50, 340-343.

68. Kim, S.Y.; Lee, H.W.; Hong, J.W.; Kang, Y.S.; Kim, J.D.; Chang, M.W.; Bae, S.K. Metal adsorption of the polysaccharide produced from Methylobacterium organophilum. Biotechnol. Lett. 1996, 18, 1161-1164.

69. Valls, M.; de Lorenzo, V. Exploiting the genetic and biochemical capacities of bacteria for the remediation of heavy metal pollution. FEMS Microbiol. Rev. 2002, 26, 327-338.

70. Moraine, R.A.; Rogovin, P. Kinetics of polysaccharide B-1459 fermentation. Biotech. Bioeng. 1966, 8, 511-524.

71. Rodríguez-Valera, F.; Ruíz-Berraquero, F.; Ramos-Comenzana, A. Characteristics of the heterotrophic bacterial populations in hypersaline environments of different salt concentrations. Microbiol. Ecol. 1981, 7, 235-243.

72. Bergmeyer, H.V.; Bent, E. Determination with glucose oxidase and peroxidase. In Method of Enzymatic Analysis; Bergmeyer, H.V., Ed.; Academic Press: New York, NY, USA, 1965; pp. 123-130.

73. Dubois, M.; Gilles, K.A.; Hamilton, J.K.; Rebers, P.A.; Smith, F. Colorimetric method for determination of sugars and related substances. Anal. Chem. 1956, 28, 350-356.

74. Bradford, M.M. A rapid and sensitive method for the quantification of microgram quantities of protein utilizing the principle protein-dye binding. Anal. Biochem. 1976, 72, 248-254.

75. McComb, E.A.; McCready, R.M. Determination of acetyl in pectin and in acetylated carbohydrate polymers. Anal. Chem. 1957, 29, 819-821.

76. Sloneker, J.H.; Orentas, D.G. Quantitative determination of pyruvic acid. Nature 1962, 194, 478.

77. Johnson, A.R. Improved method of hexosamine determination. Anal. Biochem. 1971, 44, 628-635. 
78. Chaplin, M.F. A rapid and sensitive method for the analysis of carbohydrate components in glycoproteins using gas-liquid chromatography. Anal. Biochem. 1982, 123, 336-341.

79. Cooper, D.; Goldenberg, G. Surface active agents from two Bacillus species. Appl. Environ. Microbiol. 1987, 54, 224-229.

80. Westphal, O.; Jann, K. Bacterial lipopolysaccharides: Extraction with phenol-water and further application of the procedure. In Carbohydrate Chemistry; Whistler, R.L., Ed.; Academic Press: New York, NY, 1965; pp. 83-91.

81. Laemmli, U.K. Cleavage of structural proteins during the assembly of the bacteriophage T4. Nature 1970, 227, 680-685.

82. Geddie, J.L.; Sutherland, I.W. Uptake of metals by bacterial polysaccharides. J. Appl. Bacteriol. 1993, 74, 467-472.

Sample Availability: Samples of the EPS produced by Halomonas almeriensis $\mathrm{M}^{\mathrm{T}}$ is available from the authors.

(C) 2012 by the authors; licensee MDPI, Basel, Switzerland. This article is an open access article distributed under the terms and conditions of the Creative Commons Attribution license (http://creativecommons.org/licenses/by/3.0/). 